\title{
Human Service Matters: A Cross-National Study in Restaurant Industry
}

\author{
Boo Ho Voon \\ Universiti Teknologi MARA, Malaysia \\ Johan de Jager \\ Tshwane University of Technology, South Africa \\ Krishnaswamy Chitra \\ Sri Ramakrishna Engineering College, India \\ Karen Kueh \\ Swinburne University of Technology, Malaysia \\ Patricia Melvin Jussem \\ Universiti Teknologi MARA, Malaysia
}

\begin{abstract}
The restaurant industry is becoming more important in generating income for many nations and hence the factors affecting the restaurant service performance need to be well managed. Therefore, this paper aims to explore and validate the importance of servicescape, human service, food quality and price from the customers' perspective. The restaurant customers in Malaysia, South Africa and India participated in the study. Duly completed structured questionnaires were collected. The study reveals that key determinants on satisfaction and loyalty were mainly human service and food quality.
\end{abstract}

Keywords: Human service, cross-national, restaurants.

\section{Introduction}

The restaurant industry is one of the key contributors for the service sector in many Asian and African countries. It is relatively competitive in nature with stiff competition within the industry due to an increasing number of new entrants offering differentiated food products and services. On the other hand, the customers are becoming more demanding (Stevens et al., 1995; Kueh \& Voon, 2007, Rye, Lee, and Kim, 2012) and their needs are rather diverse. Service has been recognized as one of the effective tools for gaining as well as sustaining the competitive advantage. Nevertheless, achieving superior service for the various types of customers is very 
challenging due to the nature of the restaurant industry which is characterised by high-contact and people-processing services.

Achieving high level of customer satisfaction for probable customer loyalty has been crucial to improve competitiveness of restaurants irrespective of the types. Rye et al. (2012) state that service quality and customer satisfaction have become the most core marketing priorities since they are prerequisites of customer loyalty, such as repeat sales and positive word-of-mouth.

In this respect, it is important to understand the role and relative importance of the numerous key factors which will most probably influence satisfaction and loyalty. A proper combination of vital attributes should result in customers' perceptions of high restaurant service quality, which in turn should enhance customer satisfaction and customer loyalty in the restaurant industry (Rye et al., 2012). This paper specifically investigates the factors, namely Servicescape, Human Service, Food Quality and Price in influencing the customer satisfaction and loyalty in the selected three nations. The role of the service environment is specifically targeted as the role of dining environment; atmosphere and/or tangibles are gaining attention of the service researchers in hospitality.

\section{Literature Review and Theoretical Framework}

Service researchers prefer to measure as well as investigate the relationships among service quality, customer satisfaction and behavioral intentions (e.g. Dabholkar et al., 2000; Kueh \& Voon, 2007; Qin and Prybutok, 2008; Zeithaml et al., 1996). Generally, the customer-perceived service quality is found to be positively related to behavioral intentions and loyalty. There are also researchers (e.g. Dabholkar et al., 2000; Brady and Robertson, 2001; Tam, 2004) who found that customer satisfaction mediates the effect of service quality on behavioural intentions.

On the other hand, Wong (2004) found that service quality positively would affect emotional satisfaction that in turn would have positive effect on both customer loyalty and relationship quality. Additional support for the links between service quality, customer satisfaction and loyalty has been provided by Tsoukatos and Rand (2006) who also differentiated between emotional loyalty and behavioral loyalty. Emotional loyalty was said to mediate the effect of satisfaction on behavioral loyalty. The importance of service quality on customer loyalty intentions was highlighted by Venetis and Ghauri (2004) who found that service quality affected customers' intentions to stay in a relationship with a service provider. Service quality also may affect loyalty through the mediating variables of trust and commitment (Caceres and Paparoidamis, 2007).

The servicescape (mainly tangibles) of the restaurants has also been found to affect customers' evaluations of service quality as well as post-purchase behavior (e.g. Kim and Moon, 2009, Rye, Lee and Kim, 2012). In fact, Bitner (1992) had presented a comprehensive model for understanding how the physical surroundings of a service organization may influence individual behaviors of customers. The dimensions include ambient conditions such as noise, music, scent, (Barber and Scarcelli; 2010), lighting and temperature, spatial layout which includes the arrangement of furniture 
and equipment, and signs, symbols and artefacts such as décor and signage. Bitner (1992) argued that the intangible nature of services may lead consumers to make cognitive assessments of service quality based on extrinsic cues found in the servicescape. This physical environment (Wall and Berry, 2007) may affect customers' physical comfort and movement. On the contrary, Voon et al., (2007) found that servicescape had relatively small impact on the satisfaction and loyalty of the restaurant customers. As such, this paper aims to investigate the role of the more comprehensive service environment from the youth customer's perspective.

Services rendered by employees in the restaurant industry are equally important in satisfying customers. This is the opinion of Rye et al. (2012) as well as Slatten and Mehmetoglu (2011) when they state that the restaurant industry generally use food, physical environment and employees services as key components of restaurant experience in evaluating the restaurant service quality. Nguyen and Leblanc (2002) states that guest-contact personnel amongst others had a significantly positive impact on perceived corporate image by new clients of a service company. In their study, Rye et al. (2012) listed four variables under the factor service quality and all relates to human (employee) service aspects. All of the aspects deal with the role that employees are playing in trying to satisfy the diner's eating experience when eating out. It might also include physical appearance, behaviour and attitude of the employee/waiter. Not much research has been done on a comprehensive role that these employees are playing in providing excellent service in the restaurant industry. A lack of customer care orientation is contributing to the huge shortage of chefs and waiters in South Africa and thus the reason why these positions are not filled. Frontline employees do not know why they should deliver great service while they are often not treated with respect. This industry is furthermore characterised by poor training and development, limited career progression, and low salary levels (RSA NDT, 2011). Namkung et al. (2009) conclude that services such as those offered in the hospitality industry rely heavily on the service providers' interpersonal skills as it is often the quality of interpersonal interaction between the customer and the contact employee that influences customer evaluation of services.

In addition, the role of food quality is also recognized as one of the key determinant for customer satisfaction and loyalty (Namkung et al., 2009). Good quality of food and beverages can be instrumental in satisfying and retaining the youth customers who most probably enjoy eating delicious food. There are many Malaysian youth customers who prefer hot and spicy food available in fast food and food courts. Researchers have found that the quality of menu items affects customers' intention to dine at the restaurant (e.g. Qu, 1997; Kivela et al., 2000; Soriano, 2002; Zopiatis and Pribic, 2007).

Pricing or the perceived-value of the restaurants is another factor that has been studied in relation to customer satisfaction and patronage intentions. Monetary and time costs negatively affect perceived value while perceived service quality leads to higher levels of perceived value. Furthermore, post-purchase intentions were more strongly influenced by perceived value (Tam, 2004). Qin and Prybutok (2008) also investigated the role of price/value in determining customer satisfaction for fast-food restaurants but did not find it to be of significance. This is however believed to be due to the nature of fast-food restaurants in which price is relatively low and therefore not of central importance to consumers compared to other types of establishments such as 
fine-dining restaurants. Nevertheless, to the youth who are not economically strong may find that price is important to attract them to the restaurants. Namkung et al. (2009) pointed out the importance of realizing the strategic importance of price fairness. Prices on the menus could be judged differently depending on the preconceived ideas and current experiences with a particular restaurant. However, the question of how consumer's perceptions of fairness of price are formed continues to provoke marketers' interest.

Undoubtedly, many research findings suggest that servicescape, human-related service, price and food quality have influences on customer satisfaction and loyalty. However, some studies have only considered human service quality, price and food quality without including the tangibles. On the other hand, scant attention had been given to the youth customers. This study therefore contributes to the existing research by comparing the effects of all the four factors on satisfaction and loyalty. The proposed relationships are shown in Figure 1.

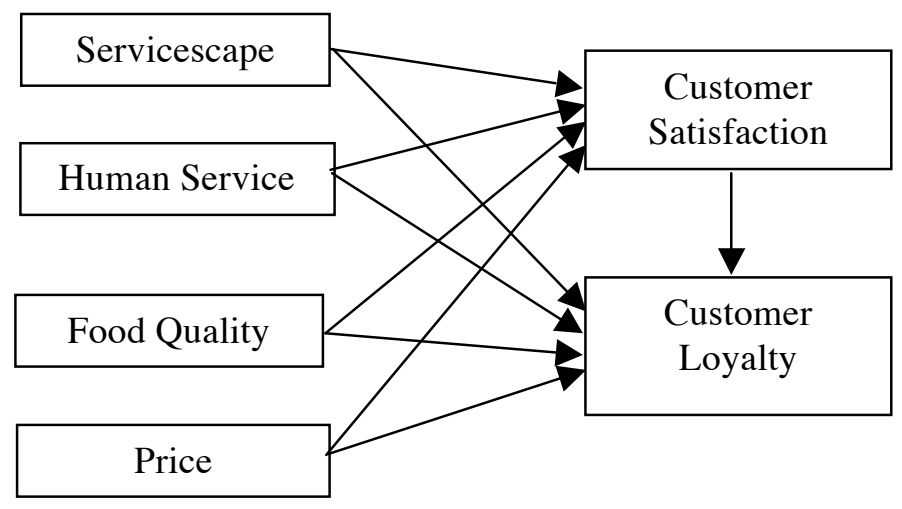

\section{Figure 1: Relationships among Servicescape, Human Service, Food Quality, Price, Customer Satisfaction and Loyalty}

\section{Methodology}

The focus of this study is mainly to validate the role of servicescape, human service, food quality and price for restaurants (Voon, 2012) in three countries (i.e., Malaysia, South Africa and India). The customers who had recently dined at the restaurants (fine dining and fast food restaurants) in the previous three months were invited to answer the structured questionnaires. These restaurants were chosen as they have the required restaurant settings and more comprehensive facilities for customer's evaluations.

The sample respondents were selected using quota sampling. The key controlled characteristics were gender, age, marital status and education. The customer characteristics are shown in Table 1. 
Table 1: The Respondent Characteristics

\begin{tabular}{|ll|c|c|c|}
\hline Demographic variables & $\begin{array}{c}\text { Malaysia } \\
(\%, \mathrm{n}=200)\end{array}$ & $\begin{array}{c}\text { South Africa } \\
(\%, \mathrm{n}=196)\end{array}$ & $\begin{array}{c}\text { India } \\
(\%, \mathrm{n}=172)\end{array}$ \\
\hline Gender: & Male & 38.5 & 43.9 & 65.7 \\
& Female & 61.5 & 56.1 & 34.3 \\
\hline Age: & 20 or less & 35.5 & 14.8 & 14.5 \\
& $21-30$ & 53.5 & 42.8 & 45.3 \\
& 31 and above & 11.0 & 42.4 & 39.5 \\
\hline Marital: & Single & 85.0 & 52.0 & 50.6 \\
& Married/Divorced & 15.0 & 48.0 & 45.9 \\
\hline \multirow{2}{*}{ Education: } & Diploma or less & 61.5 & 61.2 & 14.0 \\
& Degree & 34.0 & 16.8 & 30.8 \\
& Postgraduate & 4.5 & 21.9 & 55.2 \\
\hline
\end{tabular}

The multi-item measures for human service, price and food quality were adapted from the scales of Qin and Prybutok (2008). During exploratory factor analysis using pilot testing data, one of the dimensions for human service (namely responsiveness) was excluded due to significant cross-loading with the other service dimensions. The servicescape items were adapted from Kim and Moon (2009) and Bitner (1992) while the scales of Cronin and Taylor (1992) and Boulding et al. (1993) were adapted for measuring customer satisfaction and loyalty respectively.

The summarized items for the various measurement scales with their respective operational items are as follows:

Environment includes the things and people around us in life. As such, the Service Environment encompasses the servicescape (physical environment) and the human service aspects of the restaurants.

The items for Servicescape included in this study are: availability of parking space, cleanliness, temperature, colour scheme, smell/scent, labels/signage and design/layout. This concerns mainly the purposively created restaurant environment to serve the customers.

Human service (Assurance: well-dressed and appear neat, wear sanitary gloves and hair net, friendly, polite, knowledgeable, can be trusted; Reliability: promised service as promised, helpful, made me feel confident, charged accurately, on-schedule service; Empathy: individual attention, convenient operating hours, complete packaged food, sauces/spices always available).

Food quality (clean, healthy, fresh and has a variety)

Price (competitive price, good value for money, willing to give special prices)

Customer satisfaction (overall satisfaction, quality of service experience, meet expectation)

Customer loyalty (repurchase intention and recommend to others)

These items were measured using the 7-point Likert scale $(1=$ Strong Disagree, $7=$ Strong Agree) in the structured questionnaire. Scores closer to 7 is indicative of higher levels of satisfaction. Reliability analysis (Cronbach's alpha coefficients for measures and internal consistency method for items using item-to-total correlations) and multiple regressions were done on the respective measures to understand the goodness of measures, relative importance and relationships. 


\section{Findings and Discussions}

First of all, the goodness of the multi-item measures were evaluated accordingly. The results of the reliability tests are shown in Table 2. All the six multi-item variables (Servicescape, Human Service, Price, Food Quality, Customer Satisfaction and Loyalty) are found to be reliable as their Cronbach's alpha coefficients are close to or higher than the required level of 0.70 (Nunnally and Bernstein, 1994). The items are also showing acceptable levels of item-to-total correlation results.

Table 2: Reliability and Descriptive Statistics for Variables

\begin{tabular}{|l|c|c|c|c|c|c|c|c|c|}
\hline Variables & \multicolumn{3}{|c|}{ Malaysia } & \multicolumn{3}{c|}{ South Africa } & \multicolumn{3}{c|}{ India } \\
\cline { 2 - 12 } (no. of items) & Alpha & Mean & S.D & Alpha & Mean & S.D. & Alpha & Mean & S.D. \\
\hline Servicescape (7) & 0.84 & 4.63 & 0.92 & 0.82 & 5.32 & 1.00 & 0.74 & 5.35 & 0.79 \\
\hline Human Service (15) & 0.93 & 4.49 & 1.00 & 0.91 & 5.33 & 0.93 & 0.85 & 5.37 & 0.69 \\
\hline Food Quality (4) & 0.77 & 4.52 & 1.18 & 0.83 & 5.50 & 1.11 & 0.65 & 4.87 & 1.14 \\
\hline Price (3) & 0.79 & 4.68 & 1.00 & 0.65 & 5.50 & 0.99 & 0.79 & 5.77 & 0.88 \\
\hline $\begin{array}{l}\text { Customer Satisfaction } \\
\text { (3) }\end{array}$ & 0.83 & 4.63 & 1.16 & 0.86 & 5.57 & 1.09 & 0.66 & 5.49 & 0.82 \\
\hline Customer Loyalty (2) & 0.86 & 4.68 & 1.34 & 0.89 & 5.61 & 1.16 & 0.66 & 5.58 & 0.93 \\
\hline
\end{tabular}

The findings from this cross-national restaurants survey indicate that the customers who participated in the survey were generally satisfied with the four variables measured. However, they are particularly more satisfied with Price and Servicescape (Malaysia), Price and Food Quality (South Africa) and Price (India) aspects of the restaurants as these factors received relatively higher mean scores. This indicates that the restaurants patronized by the respondents in this study performed better in terms of the price, food quality and servicescape. Generally, the mean scores for Human Service are relatively lower. This implies that the human factor should be given due attention so to satisfy the restaurants' customers to enhance their loyalty.

The relative importance or ranking (RK) of the four factors in influencing the customer satisfaction and loyalty were also investigated (the ranking was done based on the standardized beta coefficients from the multiple regressions). The findings in Table 3 show that, for the Malaysian case, these four determinants explained $67 \%$ of the variance in customer satisfaction, South Africa (65\%) and India (only 48\%). For all the regions, Human Service is the most important factor (Rank 1) which exerted a positive and significant influence on their satisfaction.

Though the Human Service dimension of the service environment contributed much to the customer satisfaction, the Servicescape did not seem to impact their satisfaction conclusively. The results in Table 3 indicate that Servicescape, which is part of the service environment (Voon, 2012), does not seem to have significant influence on the customer satisfaction. They should have their pre-determined expectations of these restaurants. They expect the former to have very good environment where as the latter most probably less in terms of conducive and nice environment. Nevertheless, the specific tangibles which would have impacted their satisfaction should be identified for more effective service operations management. 
Table 3: Relative Importance of the Variables on Customer Satisfaction

\begin{tabular}{|c|c|c|c|c|c|c|c|c|c|}
\hline \multirow{3}{*}{$\begin{array}{l}\text { Independent } \\
\text { Variables }\end{array}$} & \multicolumn{9}{|c|}{ Customer Satisfaction } \\
\hline & \multicolumn{3}{|c|}{ Malaysia } & \multicolumn{3}{|c|}{ South Africa } & \multicolumn{3}{|c|}{ India } \\
\hline & $\beta$ & Sig. & RK & $\beta$ & Sig. & RK & $\beta$ & Sig. & RK \\
\hline Servicescape & -0.12 & .100 & 4 & -0.068 & 0.320 & 4 & 0.06 & 0.374 & 4 \\
\hline Human Service & $0.48^{*}$ & .000 & 1 & 0.492 & 0.000 & 1 & $0.39 *$ & 0.000 & 1 \\
\hline Food Quality & $0.27 *$ & .000 & 2 & 0.192 & 0.002 & 3 & $0.27 *$ & 0.000 & 2 \\
\hline Price/Value & $0.26^{*}$ & .000 & 3 & 0.294 & 0.000 & 2 & $0.16^{*}$ & 0.030 & 3 \\
\hline $\mathrm{R}^{2}$ & \multicolumn{3}{|c|}{0.67} & \multicolumn{3}{|c|}{0.65} & \multicolumn{3}{|c|}{0.48} \\
\hline
\end{tabular}

* (Significant at 0.05 level).

The findings in Table 4 show that, for Malaysian case, these four determinants explained $62 \%$ of the variance in customer loyalty, South Africa (45\%) and India $(34 \%)$. These factors influenced the customers satisfaction more than their behavioural intentions, in line with many other restaurant service research (e.g. Qin and Prybutok, 2008; Voon, 2012, Voon et al., 2009).

Human Service is also found to be crucial for customer loyalty. The results in table 4 indicate that Human Service is the most important factor for participating customers in Malaysia and South Africa, but Food Quality is the most important loyalty determinant in India. Servicescape is the least important in all the three regions.

Table 4: Relative Importance of the Variables on Customer Loyalty

\begin{tabular}{|l|c|c|c|c|c|c|c|c|c|}
\hline \multirow{3}{*}{$\begin{array}{c}\text { Independent } \\
\text { Variables }\end{array}$} & \multicolumn{9}{|c|}{ Customer Loyalty } \\
\cline { 2 - 12 } & \multicolumn{3}{|c|}{ Malaysia } & \multicolumn{3}{c|}{ South Africa } & \multicolumn{3}{c|}{ India } \\
\cline { 2 - 11 } & $\beta$ & Sig. & Rank & $\beta$ & Sig. & Rank & $\beta$ & Sig. & Rank \\
\hline Servicescape & 0.15 & .052 & 4 & 0.126 & 0.142 & 3 & 0.03 & 0.716 & 4 \\
\hline Human Service & $0.33^{*}$ & .000 & 1 & 0.362 & 0.000 & 1 & $0.23^{*}$ & 0.011 & 2 \\
\hline Food Quality & $0.26^{*}$ & .001 & 2 & 0.232 & 0.002 & 2 & $0.31^{*}$ & 0.000 & 1 \\
\hline Price/Value & $0.14^{*}$ & .027 & 3 & 0.033 & 0.650 & 4 & $0.18^{*}$ & 0.022 & 3 \\
\hline \multicolumn{4}{|c|}{0.62} & \multicolumn{4}{c|}{0.45} & \multicolumn{3}{c|}{0.34} \\
\hline
\end{tabular}

* (Significant at 0.05 level).

The critical role of Human Service in determining the customer satisfaction and loyalty is generally clear and managers should emphasize the quality of service rendered by the employees at all times. Since Servicescape ranked second in influencing satisfaction, the relative importance of its attributed was explored and the results are shown in Table 5. The significant attributes (at 0.05 level) for Malaysian customers are namely: 'Appropriate labels and signage', 'Clean dining area', 'Appropriate temperature' and 'Has a nice smell.' The customers surveyed in South Africa indicated that the smell/scent and labels/signage are more important where the customers in India emphases smell/scent and temperature. 
Table 5: Relative Importance of Servicescape Attributes on Customer satisfaction

\begin{tabular}{|l|c|c|c|c|c|c|c|c|c|}
\hline \multirow{2}{*}{\multicolumn{1}{c|}{ Attributes }} & \multicolumn{3}{c|}{ Malaysia } & \multicolumn{3}{c|}{ South Africa } & \multicolumn{3}{c|}{ India } \\
\cline { 2 - 11 } & $\beta$ & Sig. & RK & $\beta$ & Sig. & RK & $\beta$ & Sig. & RK \\
\hline $\begin{array}{l}\text { Parking space always } \\
\text { available }\end{array}$ & 0.068 & 0.276 & 5 & 0.106 & 0.100 & 4 & 0.124 & 0.133 & 3 \\
\hline Clean dining area & $0.276^{*}$ & 0.000 & 2 & 0.177 & 0.125 & 3 & 0.063 & 0.424 & 5 \\
\hline $\begin{array}{l}\text { Appropriate } \\
\text { temperature }\end{array}$ & $0.202^{*}$ & 0.003 & 3 & 0.062 & 0.394 & 5 & $0.187^{*}$ & 0.020 & 2 \\
\hline $\begin{array}{l}\text { Has appropriate colour } \\
\text { scheme }\end{array}$ & -.037 & 0.604 & 6 & 0.062 & 0.437 & 5 & -0.037 & 0.644 & 7 \\
\hline Has a nice smell (scent) & $0.188^{*}$ & 0.013 & 4 & $0.264^{*}$ & 0.001 & 1 & $0.202^{*}$ & 0.027 & 1 \\
\hline $\begin{array}{l}\text { Appropriate labels and } \\
\text { signage }\end{array}$ & $0.279^{*}$ & 0.000 & 1 & $0.192^{*}$ & 0.018 & 2 & -0.034 & 0.704 & 6 \\
\hline $\begin{array}{l}\text { Has a good design and } \\
\text { layout }\end{array}$ & -.127 & 0.080 & 7 & 0.039 & 0.596 & 6 & 0.070 & 0.426 & 4 \\
\hline
\end{tabular}

* (Significant at 0.05 level).

\section{Conclusions and Future Research}

This main purpose of this study on restaurants in three selected nations (i.e., Malaysia, Africa and India) was to examine the relative importance of four determinants of customer satisfaction and loyalty, namely, Servicescape, Human Service, Food Quality and Price. Overall, it was found that Human Service played a critical role in determining the customer satisfaction and loyalty in all the three regions.

The results indicated that customers were generally satisfied with the restaurants and the key determinants on their satisfaction and loyalty were mainly Human Service and Food Quality. The former was found to be the most important across all the three countries. However, the impact of servicescape on customer satisfaction and loyalty was found to be insignificant.

The managerial implication for restaurant managers and operators is that careful attention and proper resource allocation should be given to deliver high levels of Human Service in order to delight customers. The customer-contact service employees must be appropriately trained and monitored in terms of their skills knowledge, attitudes and relations (SKAR). The employees need to be specifically empathetic or caring, reliable, responsive and courteous. They must be motivated and emotionally stable at all times.

The findings suggest that merely emphasizing the physical environment of the restaurants will not necessarily improve the youth satisfaction and loyalty if the quality of service provided by the restaurant employees (Human Service) is lacking. The intended Service Environment includes Human Service and Servicescape. As such, a more comprehensive enhancement that is based on Service Environment will be more strategic for winning their hearts. Nevertheless, more detailed investigations with more representative samples across different cultural backgrounds will still be needed. The role of potential moderating factors such as emotional experience should be considered. Understanding the nature of relationships among the variables will add more insights for managers. The relationships or consequences could non-linear or indirect. Structural equation modelling (SEM) for examining the structural 
relationships of the various variables involved will be useful for the managers to allocate resources strategically to serve the cross-cultural and international customers.

\section{Acknowledgment}

The authors wish to thank all the research assistants who helped in the data collection and reparation processes of the research project.

\section{References}

Bitner, M.J. (1992). Servicescapes: The impact of physical surroundings on customers and employees. Journal of Marketing, 56, 57-71.

Boulding, W., Kalra, A., Staelin, R. \& Zeithaml, V. (1993). A dynamic process model of service quality: from expectations to behavioral intentions. Journal of Marketing Research, 30 (February), 7-27.

Brady, M.K. and Robertson, C.J. (2001). Searching for a consensus on the antecedent role of service quality and satisfaction: An exploratory cross-national study. Journal of Business Research, 51, 53-60.

Caceres, R.C. and Paparoidamis, N.G. (2007). Service quality, relationship satisfaction, trust, commitment and business-to-business loyalty. European Journal of Marketing, 41(7/8), 836-867.

Cronin, J.J. and Taylor, S.A. (1992). Measuring service quality: A reexamination and extension. Journal of Marketing, 56(3), 55-68.

Dabholkar, P.A., Shepherd, C.D. and Thorpe, D.I. (2000). A comprehensive framework for service quality: An investigation of critical conceptual and measurement issues through a longitudinal study. Journal of Retailing, 76(2), 139173.

Harris, L.C. and Ezeh, C. (2008). Servicescape and loyalty intentions: An empirical investigation. European Journal of Marketing, 42(3/4), 390-422.

Keillor, B.D., Lewison, D., Hult, G.T.M. and Hauser, W. (2007). The service encounter in a multi-national context. Journal of Services Marketing, 21(6), 451-461.

Kim, W.G. and Moon, Y.J. (2009). Customers' cognitive, emotional, and actionable response to the servicescape: A test of the moderating effect of the restaurant type. International Journal of Hospitality Management, 28, 144-156.

Kivela, J., Inbakaran, R. and Reece, J. (2000). Consumer research in the restaurant environment. Part 3: analysis, findings and conclusions. International Journal of Contemporary Hospitality Management, 12(1), 13-30.

Kueh, K. \& Voon, B.H. (2007). Culture and service quality expectations: Evidence from Generation Y consumers in Malaysia. Managing Service Quality, 17 (6), 656680. 
Nguyen, N and Leblanc, G. (2002). Contact personnel, physical environment and the and the perceived corporate image of of intangible services by new clients, International Journal of Service Industry Management 13 (3), 242-262.

Namkung, Y., Jang, S., Almanza, B. and Ismail, J. (2009). Identifying the underlying structure of perceived service fairness in restaurants. International Journal of Contemporary Hospitality Management, 21 (4), 375-392.

Nunnally, J.C. and Bernstein, I.H. (1994). Psychometric Theory, $3^{\text {rd }}$ Ed. New York: McGraw-Hill, Inc.

Qin, H. and Prybutok, V.R. (2008). Determinants of customer-perceived service quality in fast-food restaurants and their relationship to customer satisfaction and behavioral intentions. The Quality Management Journal, 15(2), 35-50.

Qu, H. (1997). Determinant factors and choice intention for Chinese restaurant dining: A Multivariate approach. Journal of Restaurant \& Foodservice Marketing, 2(2), 3549.

RSA NDT (Republic of South Africa National Department of Tourism). National Tourism sector strategy. Pretoria. Department of Tourism.

Rye, K., Lee, H-R and Kim, W.G. (2012). The influence of the quality of the physical environment, foods and service on restaurant image, customer perceived value, customer satisfaction and behavioural intentions. International Journal of Contemporary Hospitality Management. 24 (2), 200-223.

Reimer, A. and Kuehn, R. (2005). The impact of servicescape on quality perception. European Journal of Marketing, 39(7/8), 785-808.

Reimer, A. and Kuehn, R. (2005). The impact of servicescape on quality perception. European Journal of Marketing, 39(7/8), 785-808.

Slatten, T. and Mehmetoglu, M. (2011). Antecedentsand effects of engaged frontline employees: A study from the hospitality industry. Managing service quality. , 20 (1), 88-107.

Stevens, P., Knutson, B. and Patton, M. (1995). DINESERV: A tool for measuring service quality in restaurants. Cornell Hotel and Restaurant Administration Quarterly, 36 (2), 56-60.

Soriano, D.R. (2002). Customers' expectations factors in restaurants: The situation in Spain. International Journal of Quality \& Reliability Management, 19(8/9), 10551067.

Tam, J.L. (2004). Customer satisfaction, service quality and perceived value: An integrative model. Journal of Marketing Management, 20, 897-917.

Tsoukatos, E. and Rand, G.K. (2006). Path analysis of perceived service quality, satisfaction and loyalty in Greek insurance. Managing Service Quality, 16(5), 501519.

Venetis, K.A. and Ghauri, P.N. (2004). Service quality and customer retention: 
building long-term relationships. European Journal of Marketing, 38(11/12), 15771598.

Voon, B.H., Kueh, K., Unggah, L. And Chali, R. (2009). Customers' perception of restaurant service quality: Evidence from Malaysia. Social and Management Research Journal, 6(1), 33-50.

Voon, B.H., Chitra, K. and Kueh, K. (2009). Factors influencing customer satisfaction and loyalty in the restaurant industry: Findings from Malaysia and India. Proceedings of Asia Pacific Marketing Conference, Kuching, Malaysia.

Voon, B.H. (2012). Role of service environment: The youth customers' perspective. Procedia - Social and Behavioural Sciences, 38, 388-395.

Wall, E. and Berry, L. (2007). The combined effects of the physical environment and employee behaviour on customer perception of restaurant service quality. Cornell Hotel and Restaurant Administration Quarterly, 48(1), 59-69.

Wong, A. (2004). The role of emotional satisfaction in service encounters. Managing Service Quality, 14(5), 365-376.

Zeithaml, V.A., Berry, L.L. and Parasuraman, A. (1996). The behavioral consequences of service quality. Journal of Marketing, 60 (April), 31-46.

Zopiatis, A. and Pribic, J. (2007). College students' dining expectations in Cyprus. British Food Journal, 109(10), 765-776. 